\title{
Lobular Endocervical Glandular Hyperplasia
}

National Cancer Institute

\section{Source}

National Cancer Institute. Lobular Endocervical Glandular Hyperplasia. NCI Thesaurus.

Code C127932.

Lobular proliferations of benign-appearing small to moderate sized endocervical glands in the inner half of the cervical stroma. The glands are lined by columnar epithelial cells which contain pyloric gland-type mucin. There is minimal atypia and mitotic figures are rare. Some cases have been associated with adenocarcinoma in situ/high grade cervical glandular intraepithelial neoplasia and gastric-type adenocarcinomas. 